\title{
Methotrexate and 5-aminoimidazole-4-carboxamide riboside exert synergistic anticancer action against human breast cancer and hepatocellular carcinoma
}

\author{
Xiao-liang $\mathrm{CHENG}^{1,4}$, Tian-yan ZHOU ${ }^{1,2}$, Bo LI3 , Meng-yao $\mathrm{LI}^{2}$, Liang $\mathrm{LI}^{1,2}$, Zai-quan $\mathrm{LI}^{3, *}$, Wei $\mathrm{LU}^{1,2, *}$ \\ ${ }^{1}$ State Key Laboratory of Natural and Biomimetic Drugs, Peking University Health Science Center, Beijing 100191, China; ${ }^{2}$ Department \\ of Pharmaceutics, School of Pharmaceutical Sciences, Peking University Health Science Center, Beijing 100191, China; ${ }^{3}$ Department of \\ Radiation Medicine, School of Basic Medical Sciences, Peking University Health Science Center, Beijing 100191, China; ${ }^{4}$ Department \\ of Pharmacy, the First Affiliated Hospital of Medical College, Xi-an Jiaotong University, Xi-an 710061, China
}

\begin{abstract}
Aim: To investigate the influences of methotrexate (MTX) on the anticancer actions and pharmacokinetics of 5-aminoimidazole-4carboxamide riboside (AICA riboside) in human breast cancer and hepatocellular carcinoma.

Methods: Human breast cancer cell line MCF-7 and human hepatocellular carcinoma cell line HepG2 were examined. The cell proliferation was assessed using a sulforhodamine B assay. Western blotting and radioactivity assays were used to analyze the phosphorylation of AMPK. The DNA synthesis was analyzed with BrdU incorporation. Nude mice bearing MCF-7 cell xenografts were used to for in vivo study. MTX (50 mg/kg, ip, per week) and AICA riboside (200 mg/kg, ip, every other day) were administered the animals for 2 weeks. The concentrations of AICA riboside and its active metabolite AICA ribotide in the plasma and tumors were measured with HPLC.
\end{abstract}

Results: Synergistic cytotoxicity in vitro was observed with MTX (0.1, 0.5, and $1 \mu \mathrm{mol} / \mathrm{L})$ combined with AICA riboside (0.25-1 mmol/L) in MCF-7 cells, and with MTX (0.5 and $1 \mu \mathrm{mol} / \mathrm{L})$ combined with AICA riboside $(0.5$ and $1 \mathrm{mmol} / \mathrm{L})$ in HepG2 cells. MTX (1 $\mu$ mol/L) significantly enhanced the AICA riboside-induced AMPK activation and BrdU incorporation in both MCF-7 and HepG2 cells. Co-treatment with MTX and AICA riboside exerted more potent inhibition on the tumor growth in nude mice than either drug alone. After injection of AICA riboside (200 mg/kg, iv) in nude mice bearing MCF-7 xenografts, MTX (50 mg/kg, iv) significantly increased the concentrations of AICA riboside and its active metabolite AICA ribotide in tumors.

Conclusion: MTX and AICA riboside exert synergistic anticancer action against MCF-7 and HepG2 cells in vitro and in vivo. MTX increases the concentration of AICA riboside and its active metabolite AICA ribotide in tumors in vivo.

Keywords: methotrexate; 5-aminoimidazole-4-carboxamide riboside; antitumor agents; human breast cancer; human hepatocellular carcinoma; drug synergism; pharmacokinetics; AMP-activated protein kinase; DNA synthesis

Acta Pharmacologica Sinica (2013) 34: 951-959; doi: 10.1038/aps.2013.16; published online 22 Apr 2013

\section{Introduction}

5-Aminoimidazole-4-carboxamide riboside (AICA riboside), a cell permeable nucleoside, was the first compound reported to activate AMP-activated protein kinase $(\mathrm{AMPK})^{[1]}$. AICA riboside is taken up into cells by adenoside transporters and is then converted by adenoside kinase to the monophosphorylated derivative AICA ribotide, which mimics the effect of AMP in activation of AMPK ${ }^{[2,3]}$. AMPK is a sensor of cel-

\footnotetext{
* To whom correspondence should be addressed.

E-mail luwei_pk@bjmu.edu.cn (Wei LU); lizaiquan@bjmu.edu.cn (Zai-quan LI)

Received 2012-11-23 Accepted 2013-02-17
}

lular energy status, and is activated under conditions of an elevated ratio of AMP to ATP. Activated AMPK inhibits tumor cell proliferation through activating elongation factor-2 and inhibiting key metabolic enzymes such as acetyl-CoA carboxylase 1, glycerol phosphate acyl transferase and HMGCoA reductase ${ }^{[4,5]}$. In addition, AMPK is associated with liver kinase B1 (LKB1), mammalian target of rapamycin (mTOR), p53 and other tumor suppressors ${ }^{[6-8]}$. AICA riboside has an inhibitory effect on the proliferation of a variety of human cancer cell lines such as B-cell chronic lymphocytic leukemia cells $^{[9]}$, chronic myelogenous leukemia cells ${ }^{[10]}$, gastric cancer cells $^{[11]}$, cervical cancer cells ${ }^{[12]}$, prostate cancer cells ${ }^{[13]}$ and hepatocellular carcinoma cells ${ }^{[14]}$. AICA riboside also has 
potent antitumor activity in nude mice bearing MDA-MB-231 and $\mathrm{C} 6$ cell xenografts ${ }^{[15,16]}$. The first patient was enrolled in a phase I/II trial of AICA riboside treatment for B-cell chronic lymphocytic leukemia in $2008^{[17]}$.

As a result of the rapid biotransformation of AICA ribotide to 10-formyl AICA ribotide, which participates in the de novo purine synthesis pathway, the most obvious disadvantage of AICA riboside is its poor pharmacokinetic profile, with a short half-life $\left(t_{1 / 2}\right)$ of $1.4 \mathrm{~h}$ in healthy volunteers ${ }^{[18]}$. This shortcoming may be overcome by coadministration of another drug that inhibits de novo purine synthesis. Methotrexate (MTX), a classical folic acid antagonist, has been one of the most widely used anticancer agents since $1948^{[19]}$. MTX polyglutamates inhibit de novo purine biosynthesis through their action on the key enzymes of de novo purine biosynthesis, including AICA ribotide transformylase, which converts AICA ribotide to 10-formyl AICA ribotide ${ }^{[20]}$.

Combined chemotherapy is a common practice in the treatment of cancer and can achieve better therapeutic effects than single drug treatment and can also reduce side effects and drug resistance ${ }^{[21,22]}$. Beckers et al have reported that MTX enhances the antianabolic and antiproliferative effects of AICA riboside ${ }^{[23]}$. The present study was aimed at investigating the combined effects of MTX and AICA riboside on tumor cell proliferation in vitro and in vivo and the influence of MTX on the pharmacokinetics of AICA riboside in nude mice bearing MCF-7 cell xenografts.

\section{Materials and methods Reagents}

AICA riboside and AICA ribotide were obtained from Toronto Research Chemicals (Toronto, Canada). MTX and sulforhodamine B were purchased from Sigma-Aldrich (Milwaukee, WI, USA). RPMI-1640 medium was obtained from Macgene Biotech Co Ltd (Beijing, China), and fetal bovine serum (FBS) was purchased from Gibco (Grand Island, NY, USA). Cellular BrdU ELISA kit was obtained from CycLex Co Ltd (Nagano, Japan). Antibody against $\beta$-actin was obtained from Abmart (Shanghai, China). Antibody against phospho-Thr172 AMPK $a$ and horseradish peroxidase (HRP)-conjugated secondary antibodies were purchased from Cell Signaling Technology (Danvers, MA, USA). SAMS peptide was obtained from GenScript USA Inc (Piscataway, NJ, USA).

\section{Cell culture}

The human breast cancer cell line MCF-7 and human hepatocellular carcinoma cell line HepG2 were purchased from the Cell Bank of the Cancer Institute \& Hospital, Chinese Academy of Medical Science (Beijing, China). MCF-7 cells were cultured in RPMI-1640 medium supplemented with 10\% FBS, 100 $\mathrm{U} / \mathrm{mL}$ penicillin and $100 \mu \mathrm{g} / \mathrm{mL}$ streptomycin, and HepG2 cells were grown in Dulbecco's modified Eagle's medium containing 10\% FBS, $100 \mathrm{U} / \mathrm{mL}$ penicillin and $100 \mu \mathrm{g} / \mathrm{mL}$ streptomycin. Cells were maintained at $37^{\circ} \mathrm{C}$ in a $5 \% \mathrm{CO}_{2}$ incubator.

\section{In vitro cytotoxicity assay}

The sulforhodamine B (SRB) assay was performed according to the method developed by Vichai ${ }^{[24]}$. MTX and AICA riboside were dissolved in pH 7.4 PBS. MCF-7 and HepG2 cells were plated at a density of $1 \times 10^{4}$ cells per well in 96-well plates. After incubation for $24 \mathrm{~h}$, cells were pretreated with $0.1,0.5$, or $1 \mu \mathrm{mol} / \mathrm{L} \mathrm{MTX}$. Four hours later, cells were exposed to 0.125, $0.25,0.5$, and $1 \mathrm{mmol} / \mathrm{L}$ AICA riboside. At the time of MTX addition, cells in one plate were fixed in situ with cold $10 \%$ $(w / v)$ trichloroacetic acid (TCA), to represent a measurement of the cell population at the time of drug addition $\left(O D_{\mathrm{d} 0}\right)$. After incubation for another $48 \mathrm{~h}$, cells were fixed in situ with cold $10 \%$ TCA. The plates were washed with tap water, stained with $0.4 \%$ SRB ( $w / v$, dissolved in $1 \%$ acetic acid), and washed with $1 \%$ acetic acid. The protein-bound dye was subsequently dissolved in $10 \mathrm{mmol} / \mathrm{L}$ Tris. The absorbance at $540 \mathrm{~nm}$ was read on a colorimetric plate reader (Bio-Rad, USA).

Percentage of cell survival was calculated as followed:

Percentage of cell survival $=\frac{\text { mean } O D_{\text {sample }}-\text { mean } O D_{\mathrm{d} 0}}{\text { mean } O D_{\text {control }}-\text { mean } O D_{\mathrm{d} 0}} \times 100$

If $O D_{\text {sample }}$ was below $O D_{\mathrm{d} 0}$, cell killing had occurred, and the percentage of cells killed was expressed by the following equation:

$$
\text { Percentage of cells killed }=100-\frac{\text { mean } O D_{\text {sample }}}{\text { mean } O D_{\mathrm{d} 0}} \times 100
$$

\section{Drug interaction analysis}

The combined effect was analyzed using published methods ${ }^{[25,26]}$ based on the principles described by Chou and Talalay $^{[27]}$. The expected $O D$ value for the combined effect of MTX and AICA riboside was calculated as follows:

Expected $O D$ value for the combined effect

$$
=\frac{\text { observed } O D_{\mathrm{MTX}}}{O D_{\mathrm{d} 0}} \times \frac{\text { observed } O D_{\text {AICA riboside }}}{O D_{\text {control }}} \times O D_{\text {control }}
$$

The combination index $(\mathrm{CI})$ was calculated as the ratio of (observed $O D$ value)/(expected $O D$ value $)^{[26]}$. Synergism was defined as $\mathrm{CI}<1$, whereas $\mathrm{CI}>1$ indicated antagonism, and $\mathrm{CI}=1$ meaned addition. $\mathrm{CI}<0.7$ indicated that the drugs were significantly synergistic.

\section{Immunoblot analysis}

MCF-7 and HepG2 cells were pretreated with $1 \mu \mathrm{mol} / \mathrm{L}$ MTX or vehicle ( $\mathrm{pH} 7.4 \mathrm{PBS}$ ), and treated with AICA riboside $4 \mathrm{~h}$ later, and then after incubation for $3 \mathrm{~h}$, cells were lysed in RIPA buffer $(50 \mathrm{mmol} / \mathrm{L}$ Tris $\mathrm{pH} 7.4,150 \mathrm{mmol} / \mathrm{L} \mathrm{NaCl}$, $1 \%$ NP-40, 0.5\% sodium deoxycholate, and 0.1\% SDS) with $1 \mathrm{mmol} / \mathrm{L}$ protease inhibitor phenylmethylsulfonylfluoride (PMSF) and 1\% phosphatase inhibitors mixture for $30 \mathrm{~min}$ on ice. The protein concentration was determined with a BCA protein assay kit (Beyotime Biotechnology, Haimen, China). Proteins were resolved by $10 \%$ SDS-PAGE and transferred to polyvinylidenedifluoride membranes. The membranes were 
blocked in Tris buffered saline with Tween 20 (TBST) containing $5 \%$ nonfat dry milk or bovine serum albumin (BSA) for $1 \mathrm{~h}$ at room temperature and incubated with antibody against $\beta$-actin (1:5000, diluted in TBST with 5\% nonfat dry milk) or phospho-Thr172 AMPK a (1:2000, diluted in TBST with 5\% BSA) overnight at $4^{\circ} \mathrm{C}$. Membranes were washed three times with TBST for $10 \mathrm{~min}$ and incubated with HRP-conjugated secondary antibodies (1:3000) for $1 \mathrm{~h}$ at room temperature, washed again, and detected by adding chemiluminescence detection solution. The protein bands were visualized by ChemiDoc XRS+ System (Bio-Rad, USA).

\section{AMPK activity assay}

Measurement of AMPK activity was carried out as described previously ${ }^{[28]}$. MCF-7 or HepG2 cells were treated as described for immunoblot analysis, and lysed in homogenization buffer (20 mmol/L Tris $\mathrm{pH} \mathrm{7.5,} 150 \mathrm{mmol} / \mathrm{L} \mathrm{NaCl}$, and 1\% Triton X-100) with $1 \mathrm{mmol} / \mathrm{L}$ protease inhibitor PMSF and 1\% phosphatase inhibitors mixture for $30 \mathrm{~min}$ on ice. Fifty microliters of $25 \%$ polyethylene glycol 6000 (PEG 6000) was added to 450 $\mu \mathrm{L}$ cell lysate supernatant, and the mixture was centrifuged at $11750 \times g$ for $10 \mathrm{~min}$. Supernatant $(450 \mu \mathrm{L})$ was removed to another tube and $50 \mu \mathrm{L} \mathrm{25 \%} \mathrm{PEG} 6000$ was added to the supernatant (final PEG 6000 concentration, 4.75\%), and the mixture was centrifuged at $11750 \times g$ for $10 \mathrm{~min}$. The resultant pellets were dissolved and assayed for AMPK activity with SAMS peptide $(20 \mu \mathrm{mol} / \mathrm{L})$ in the presence of $5 \mu \mathrm{Ci}\left[\gamma^{-}{ }^{32} \mathrm{P}\right] \mathrm{ATP}, 200$ $\mu \mathrm{mol} / \mathrm{L}$ ATP $, 200 \mu \mathrm{mol} / \mathrm{L} \mathrm{AMP,} 5 \mathrm{mmol} / \mathrm{L} \mathrm{MgCl}_{2}, 40 \mathrm{mmol} / \mathrm{L}$ HEPES, $80 \mathrm{mmol} / \mathrm{L} \mathrm{NaCl}, 8 \mathrm{mmol} / \mathrm{L}$ mannitol, $800 \mu \mathrm{mol} / \mathrm{L}$ EDTA, $800 \mu \mathrm{mol} / \mathrm{L}$ dithiothreitol, and 0.01\% Brij-35. After incubation for $15 \mathrm{~min}$ at $30^{\circ} \mathrm{C}$, the reaction mixture was spotted onto Whatman P81 paper. The papers were washed with $1 \%$ phosphoric acid $(v / v)$ four times and $\left[{ }^{32} \mathrm{P}\right]$ was counted with a scintillation counter (Packard Bioscience, USA).

\section{DNA synthesis analysis}

MCF-7 or HepG2 cells were seeded at $1 \times 10^{4}$ cells per well in a 96-well plate. Twenty-four hours later, cells were pretreated with $1 \mu \mathrm{mol} / \mathrm{L}$ MTX or vehicle, and $4 \mathrm{~h}$ later with AICA riboside. After treatment for a further $24 \mathrm{~h}$, cells were incubated with $10 \mu \mathrm{mol} / \mathrm{L}$ bromodeoxyuridine (BrdU) solution for $2 \mathrm{~h}$. The cells were incubated with fixing/denaturing solution for $30 \mathrm{~min}$ at room temperature, and were subsequently incubated with anti-BrdU monoclonal antibody for $1 \mathrm{~h}$. After washing thoroughly, cells were incubated with HRP-conjugated antimouse IgG for $1 \mathrm{~h}$. The plate was washed, and the culture was incubated with substrate for $15 \mathrm{~min}$ at room temperature. The stop solution was added to terminate the reaction. Absorbance of the samples was measured using a colorimetric plate reader (Bio-Rad, USA) at $450 \mathrm{~nm}$ (with $540 \mathrm{~nm}$ as reference wavelength). Relative BrdU incorporation was calculated as the ratio of $O D_{\text {sample }} / O D_{\text {control}}$.

\section{Tumor growth inhibition studies}

Female BALB/c nude mice (5 weeks old) were purchased from the Experimental Animal Center, Peking University
Health Science Center (Beijing, China). Animal welfare and experimental procedures strictly adhered to the Principles of Laboratory Animal Care (National Institutes of Health Publication No 86-23, revised 1985). MCF-7 cells $\left(2 \times 10^{6}\right)$ were suspended in $200 \mu \mathrm{L}$ PBS, and inoculated subcutaneously in the right flank. The mice were randomly divided into control, MTX, AICA riboside and combined MTX and AICA riboside groups, with eight mice each. The treatment was started when the average tumor volume reached $\sim 100 \mathrm{~mm}^{3}$. MTX and AICA riboside were dissolved in PBS ( $\mathrm{pH} 7.4)$. MTX (50 $\mathrm{mg} / \mathrm{kg}$ ) was injected ip once weekly, and $200 \mathrm{mg} / \mathrm{kg}$ AICA riboside was administered ip every other day. The first dose of AICA riboside was administered $4 \mathrm{~h}$ later than that of MTX. The treatment lasted for 2 weeks. The control group received vehicle alone (PBS pH 7.4). The tumor sizes were measured using calipers, and tumor volumes were calculated using the formula $A \times B^{2} / 2$, where $A$ and $B$ are the larger and smaller diameter of the tumor, respectively.

\section{Pharmacokinetics study}

MCF-7 cells were inoculated in female BALB/c nude mice as described above. When the tumor volume reached $\sim 1000$ $\mathrm{mm}^{3}$, the mice were randomly divided into two groups of 24 . One group was injected iv with $50 \mathrm{mg} / \mathrm{kg}$ MTX via the tail vein, and $4 \mathrm{~h}$ later, $200 \mathrm{mg} / \mathrm{kg}$ AICA riboside was administered iv. Another group was administered with the same dose of AICA riboside alone. Blood samples were obtained at 5, 10, 15 and $30 \mathrm{~min}$, and 1, 2, 3, and $4 \mathrm{~h}$ after injection of AICA riboside, and then centrifuged at $1110 \times \mathrm{g}$ for $10 \mathrm{~min}$ at $4^{\circ} \mathrm{C}$. The upper plasma was collected and stored at $-80^{\circ} \mathrm{C}$ before analysis. Mice were sacrificed immediately following blood collection, and tumor samples were removed from the mice and frozen at $-80^{\circ} \mathrm{C}$. PBS $(250 \mu \mathrm{L}, \mathrm{pH} 2.5)$ was added per 250 $\mathrm{mg}$ tumor tissue and tumor tissue was homogenized.

The concentrations of AICA riboside and its active metabolite AICA ribotide in plasma and tumors were assayed by an HPLC method developed by Cheng et al ${ }^{[29]}$. The pharmacokinetic parameters of AICA riboside and its active metabolite AICA ribotide in nude mouse plasma and tumors were estimated by non-compartment analysis. $C_{\max }$ was the observed maximum concentration. Mean residence time (MRT) was calculated as the ratio of the area under the first moment versus time curve $\left(\mathrm{AUMC}_{0-\infty}\right)$ to the area under the concentration versus time curve $\left(\mathrm{AUC}_{0-\infty}\right) . t_{1 / 2}$ was calculated as $0.693 \times \mathrm{MRT}$, and systemic clearance was obtained from the equation $\mathrm{CL}=\mathrm{D} / \mathrm{AUC}_{0-\infty}$, where $\mathrm{D}$ was the dose of $\mathrm{AICA}$ riboside. The apparent volume of distribution was calculated from the equation $V=D \times \mathrm{AUMC}_{0-\infty} / \mathrm{AUC}_{0-\infty}{ }^{2}$.

\section{Statistical analysis}

Data were expressed as mean \pm SD. Statistical analyses among groups were performed using one-way analysis of variance with Fisher's least significant test, and statistical analyses between two groups were done using student's $t$-test. Relative tumor volumes were compared using Mann-Whitney $U$ test followed by Bonferroni's multiple-comparison test. A value of 
$P<0.05$ was considered to be significant.

\section{Results}

Combined MTX and AICA riboside displayed more potent cytotoxicity against tumor cells than either drug alone

MCF-7 and HepG2 cells were pretreated with MTX, and $4 \mathrm{~h}$ later were exposed to AICA riboside for a further $48 \mathrm{~h}$. Cell viability was evaluated using the SRB assay (Figure 1). The percentage of MCF-7 cell survival after treatment with 0.125 , $0.25,0.5$, and $1 \mathrm{mmol} / \mathrm{L}$ AICA riboside was $66.64 \% \pm 5.00 \%$, $85.13 \% \pm 5.99 \%, 65.74 \% \pm 5.42 \%$, and $17.02 \% \pm 4.64 \%$, respectively. When MCF-7 cells were pretreated with $1 \mu \mathrm{mol} / \mathrm{L}$ MTX (the percentage of cell survival after treatment with $1 \mu \mathrm{mol} / \mathrm{L}$ MTX was $27.74 \% \pm 0.97 \%$ ), the percentage of cell survival after treatment with $0.125,0.25,0.5$, and $1 \mathrm{mmol} / \mathrm{L}$ AICA riboside was $8.46 \% \pm 0.87 \%,-3.92 \% \pm-0.29 \%,-16.48 \% \pm-1.04 \%$, and $-21.41 \% \pm-3.40 \%(P<0.001$ versus the MTX or AICA riboside group), respectively. For HepG2 cells, the percentage of cell survival after treatment with $0.25,0.5$, and $1 \mathrm{mmol} / \mathrm{L}$ AICA riboside was $47.25 \% \pm 4.55 \%, 49.85 \% \pm 4.60 \%$, and $47.20 \% \pm 8.18 \%$, respectively. When HepG2 cells were pretreated with 1 $\mu \mathrm{mol} / \mathrm{L}$ MTX (the percentage of cell survival after treatment with $1 \mu \mathrm{mol} / \mathrm{L}$ MTX was $13.26 \% \pm 0.90 \%$ ), the percentage of cell survival after treatment with $0.25,0.5$, and $1 \mathrm{mmol} / \mathrm{L}$ AICA riboside was $-1.80 \% \pm-0.12 \%,-24.58 \% \pm-3.89 \%$, and
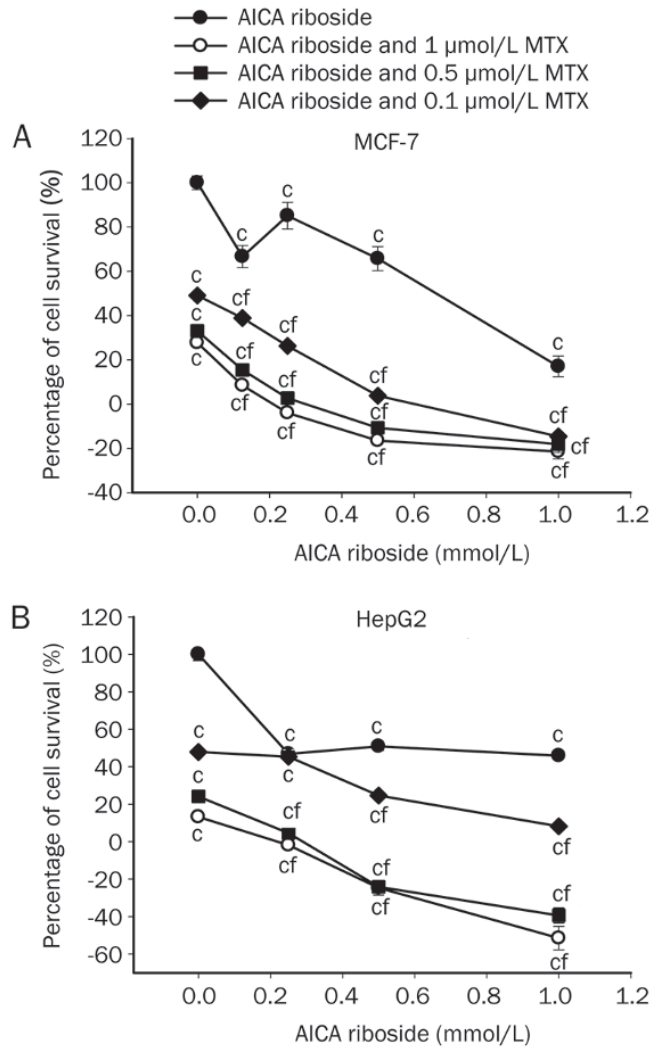

Figure 1. Combined effects of MTX and AICA riboside on inhibition of MCF-7 (A) and HepG2 (B) cell proliferation in vitro. Data are presented as mean $\pm \operatorname{SD}(n=6)$. ${ }^{\mathrm{c}} P<0.01$ versus control group. ${ }^{\mathrm{f}} P<0.01$ versus either MTX or AICA riboside treated group.
$-51.46 \% \pm-6.28 \%(P<0.001$ versus MTX or AICA riboside group), respectively. The combination of 0.1 or $0.5 \mu \mathrm{mol} / \mathrm{L}$ MTX with AICA riboside also exhibited more potent cytotoxicity than either drug alone. Percentage of cell survival $<0$ means that the treatment could kill tumor cells ${ }^{[24]}$. We showed that MTX or AICA riboside used alone mainly inhibited tumor cell proliferation, while combined treatment killed the tumor cells.

\section{Synergistic cytotoxicity of combined MTX and AICA riboside}

A CI $<1$ indicates a synergistic interaction between MTX and AICA riboside. All combinations displayed synergistic cytotoxicity against MCF-7 cells except that of $0.1 \mu \mathrm{mol} / \mathrm{L}$ MTX and $0.125 \mathrm{mmol} / \mathrm{L}$ AICA riboside (Figure 2). For HepG2 cells, the CI for $1 \mathrm{mmol} / \mathrm{L}$ AICA riboside and 0.5 or $1 \mu \mathrm{mol} / \mathrm{L} \mathrm{MTX}$ was 0.50 and 0.44 , respectively, indicating that these combinations exerted significant synergism. The results suggest that the combination of MTX and AICA riboside has a synergistic effect on the inhibition of proliferation of MCF-7 and HepG2 cell lines.

\section{MTX enhanced the ability of AICA riboside to activate AMPK}

MCF-7 or HepG2 cells were exposed to AICA riboside for $3 \mathrm{~h}$, and then phosphorylation at Thr172 of the a catalytic subunit of AMPK was investigated by Western blot analysis
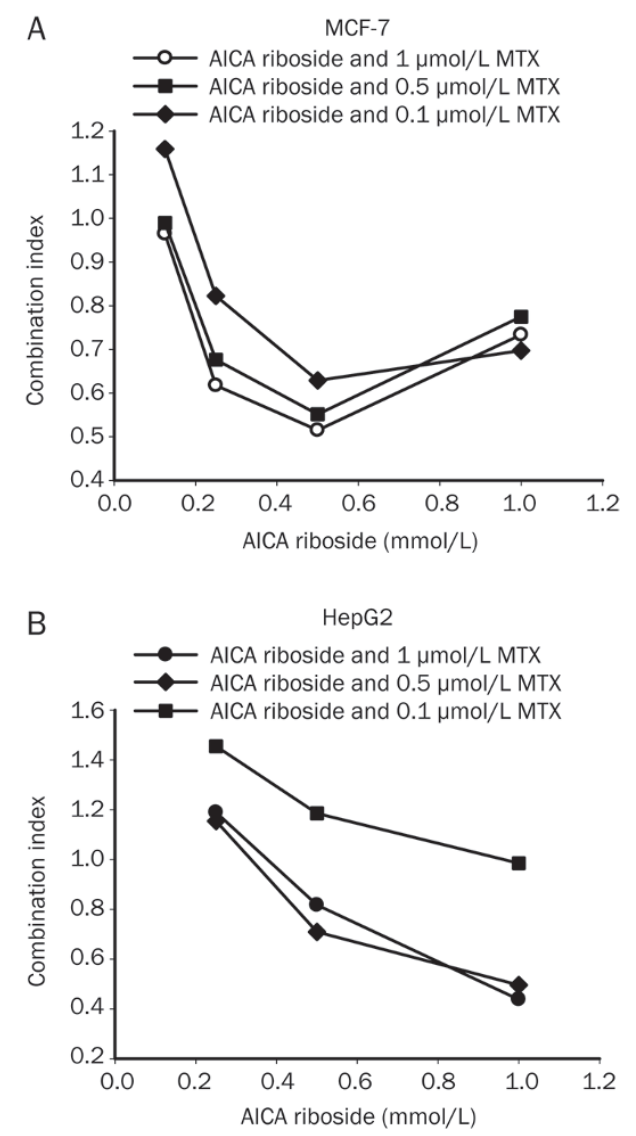

Figure 2. Synergistic effect of MTX and AICA riboside on inhibition of MCF-7 (A) and HepG2 (B) cell proliferation in vitro. $\mathrm{Cl}<1$ means synergism. 
with phospho-AMPK-specific antiserum. As shown in Figure $3 \mathrm{~A}$, phosphorylation of AMPK increased with increasing AICA riboside concentration. In addition, when cells were pretreated with $1 \mu \mathrm{mol} / \mathrm{L} \mathrm{MTX}$ for $4 \mathrm{~h}$ and then exposed to AICA riboside, the phosphorylated AMPK increased significantly compared with that of cells without MTX pretreatment. The results demonstrated that MTX pretreatment potently increased the ability of AICA riboside to phosphorylate AMPK in MCF-7 and HepG2 cells.

The activity of AMPK was determined by analyzing the

A

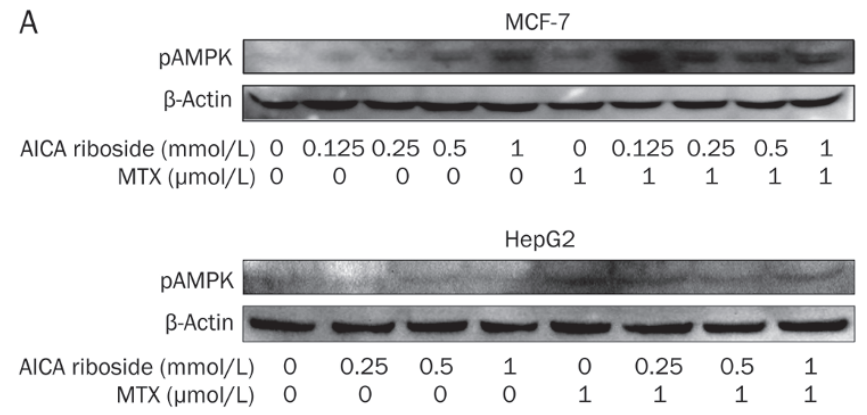

B
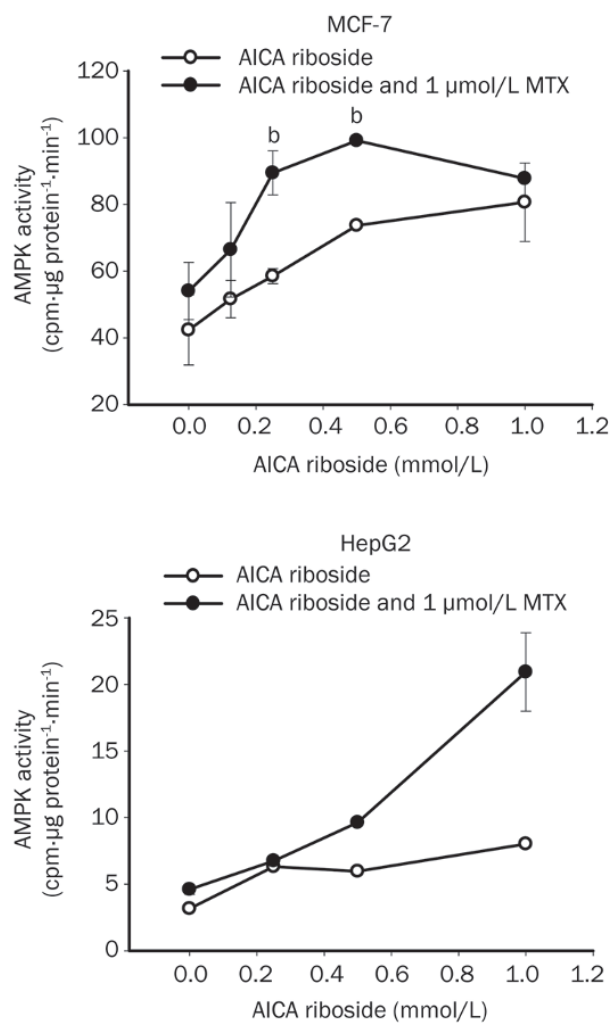

Figure 3. Effect of MTX, AICA riboside, and their combination on AMPK phosphorylation and activity. (A) $100 \mu$ g protein was subjected to Western blot analysis with antibody against phospho-Thr172 AMPK $\alpha$ (pAMPK) or $\beta$-actin. Results are representative of three independent experiments. (B) Purified proteins were assayed for their ability to phosphorylate SAMS in vitro in the presence of $\left[\mathrm{Y}^{-}{ }^{32} \mathrm{P}\right] \mathrm{ATP}$. Values were corrected for differences in protein concentration, and expressed as mean \pm SD $(n=2) .{ }^{b} P<0.05$, significantly different from cells treated with the same concentration of AICA riboside but without MTX. level of incorporation of $\left[{ }^{32} \mathrm{P}\right]$ into SAMS peptide, which is a specific substrate of AMPK. Treatment of MCF-7 or HepG2 cells with AICA riboside resulted in increased AMPK activity, and pretreatment with $1 \mu \mathrm{mol} / \mathrm{L}$ MTX enhanced the ability of AICA riboside to activate AMPK (Figure 3B). AMPK activity of MCF-7 cells after incubation with $0.125,0.25,0.5$ and $1 \mathrm{mmol} / \mathrm{L}$ AICA riboside for $3 \mathrm{~h}$ was $51.63 \pm 5.59,58.51 \pm 2.25$, $73.68 \pm 0.82$, and $80.64 \pm 11.74 \mathrm{cpm} \cdot \mu \mathrm{g}$ protein ${ }^{-1} \cdot \mathrm{min}^{-1}$, respectively, and when cells were pretreated with $1 \mu \mathrm{mol} / \mathrm{L}$ MTX for $4 \mathrm{~h}$, AMPK activity of MCF-7 cells after exposure to AICA riboside with the above concentrations was $66.43 \pm 14.16$, $89.43 \pm 6.62,99.10 \pm 0.98$, and $87.75 \pm 0.61 \mathrm{cpm} \cdot \mu \mathrm{g}$ protein ${ }^{-1} \cdot \mathrm{min}^{-1}$, respectively. Similarly, the AMPK activity of HepG2 cells when cotreated with AICA riboside and MTX was higher than that treated with AICA riboside alone.

\section{Combined effect of MTX and AICA riboside in blocking DNA synthesis}

It is known that MTX and its polyglutamates block de novo nucleotide synthesis ${ }^{[30]}$. AICA riboside has also been shown to inhibit DNA synthesis ${ }^{[15]}$. Incorporation of the thymidine analog BrdU was measured to investigate the effect of MTX and AICA riboside on blocking tumor cell DNA synthesis. Treatment of MCF-7 or HepG2 cells with AICA riboside caused a potent and dose-dependent reduction in BrdU incorporation, and combination of AICA riboside and 1 $\mu \mathrm{mol} / \mathrm{L}$ MTX resulted in greater reduction of BrdU incorporation (Figure 4). The relative BrdU incorporation of MCF-7 cells after treatment with $0.125,0.25,0.5$, and $1 \mathrm{mmol} / \mathrm{L}$ AICA riboside for $24 \mathrm{~h}$ was $96.60 \% \pm 1.83 \%, 89.43 \% \pm 8.06 \%$, $57.69 \% \pm 7.43 \%$, and $32.43 \% \pm 2.62 \%$, respectively, and when cells were pretreated with $1 \mathrm{\mu mol} / \mathrm{L}$ MTX for $4 \mathrm{~h}$, the relative BrdU incorporation after exposure to $0.125,0.25,0.5$, and $1 \mathrm{mmol} / \mathrm{L}$ AICA riboside for $24 \mathrm{~h}$ was $56.93 \% \pm 3.01 \%$, $54.40 \% \pm 4.50 \%, 40.19 \% \pm 4.04 \%$, and $2.96 \% \pm 1.25 \%$, respectively $(P<0.005$ versus either MTX or AICA riboside treated group). The relative BrdU incorporation in HepG2 cells after treatment with $0.25,0.5$, and $1 \mathrm{mmol} / \mathrm{L}$ AICA riboside for $24 \mathrm{~h}$ was $96.62 \% \pm 8.09 \%, 60.31 \% \pm 11.01 \%$, and $26.21 \% \pm 1.42 \%$, respectively, and when cells were pretreated with $1 \mu \mathrm{mol} / \mathrm{L}$ MTX for $4 \mathrm{~h}$, the relative BrdU incorporation after treatment with 0.25 , 0.5 , and $1 \mathrm{mmol} / \mathrm{L}$ AICA riboside for $24 \mathrm{~h}$ was $35.81 \% \pm 2.71 \%$, $28.93 \% \pm 3.95 \%$, and $19.46 \% \pm 3.05 \%$, respectively.

\section{Synergistic effect of MTX and AICA riboside on tumor growth in vivo}

The in vivo antitumor efficacy of combined MTX and AICA riboside was evaluated in female BALB/c nude mice bearing MCF-7 cell xenografts. Figure 5 shows the relative tumor volume (mean $\pm S D$ ) of different treatment groups over time. The combination of MTX and AICA riboside achieved a superior antitumor effect than either drug alone. MTX and AICA riboside alone inhibited tumor growth by $55.00 \% \pm 0.79 \%$ and $42.16 \% \pm 12.15 \%$ at $\mathrm{d} 14$, respectively. Combination of MTX and AICA riboside showed more potent antitumor activity with $79.92 \% \pm 34.61 \%$ inhibition of tumor growth. 

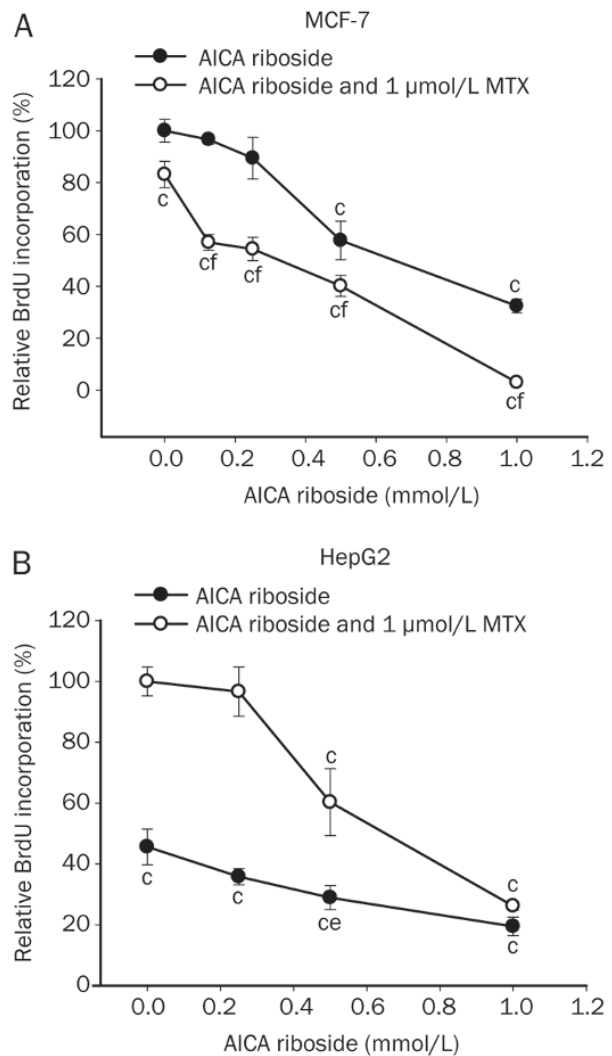

Figure 4. The combined effect of MTX and AICA riboside on inhibition of cancer cell DNA synthesis. Data are presented as mean $\pm \operatorname{SD}(n=3)$. ${ }^{c} P<0.01$ versus control group. ${ }^{\mathrm{e}} P<0.05,{ }^{f} P<0.01$ versus either MTX or AICA riboside treated group.
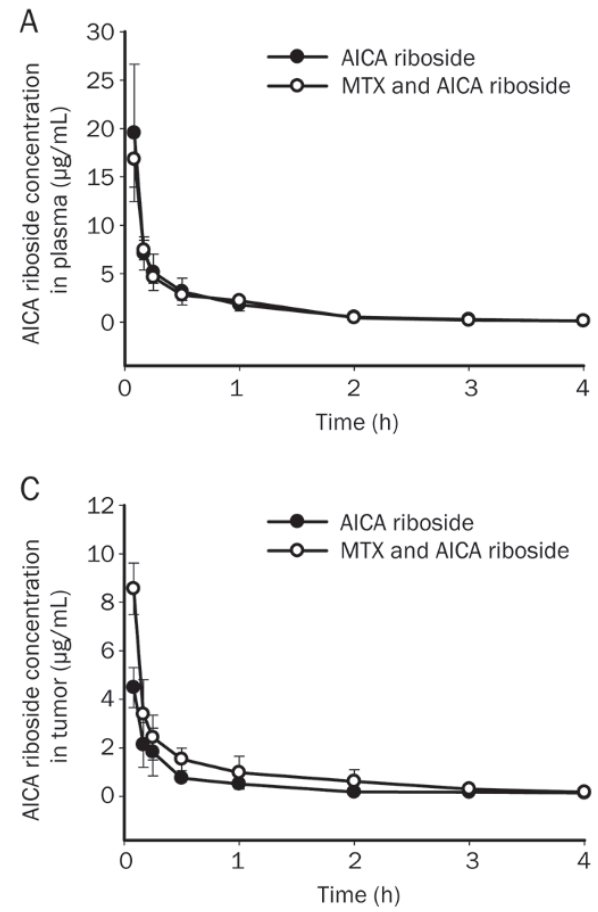

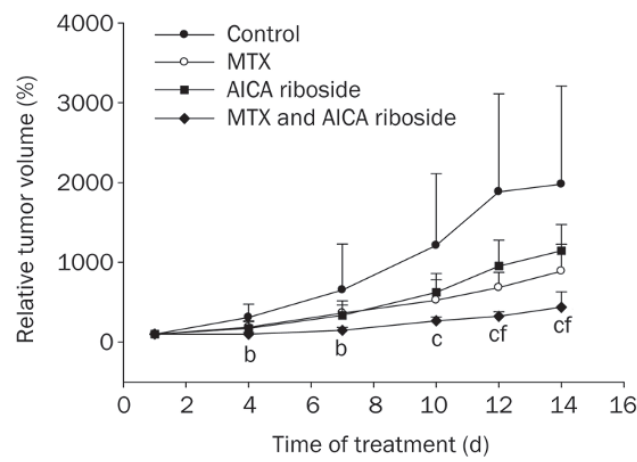

Figure 5. Effect of MTX, AICA riboside and their combination on the growth of MCF-7 cell xenografts in BALB/c nude mice. Data are presented as mean $\pm \operatorname{SD}(n=8) .{ }^{b} P<0.05,{ }^{c} P<0.01$ versus control group. ${ }^{f} P<0.01$ versus either MTX or AICA riboside treated group.

MTX increased AICA riboside and its active metabolite in tumor tissue

As shown in Figure 6, MTX had no influence on concentration of AICA riboside and AICA ribotide in plasma, but increased concentration of both AICA riboside and AICA ribotide in tumors, especially for AICA ribotide. The $C_{\max }$ of AICA riboside and its active metabolite AICA ribotide in tumors after intravenous administration of $200 \mathrm{mg} / \mathrm{kg}$ AICA riboside alone was $4.49 \pm 0.82 \mu \mathrm{g} / \mathrm{mL}$ and $8.33 \pm 0.49 \mu \mathrm{g} / \mathrm{mL}$, respectively, while the $C_{\max }$ of AICA riboside and AICA ribotide in tumors after iv injection of the same dose of AICA riboside at $4 \mathrm{~h}$ after iv administration of $50 \mathrm{mg} / \mathrm{kg}$ MTX was $8.56 \pm 1.06 \mu \mathrm{g} / \mathrm{mL}$
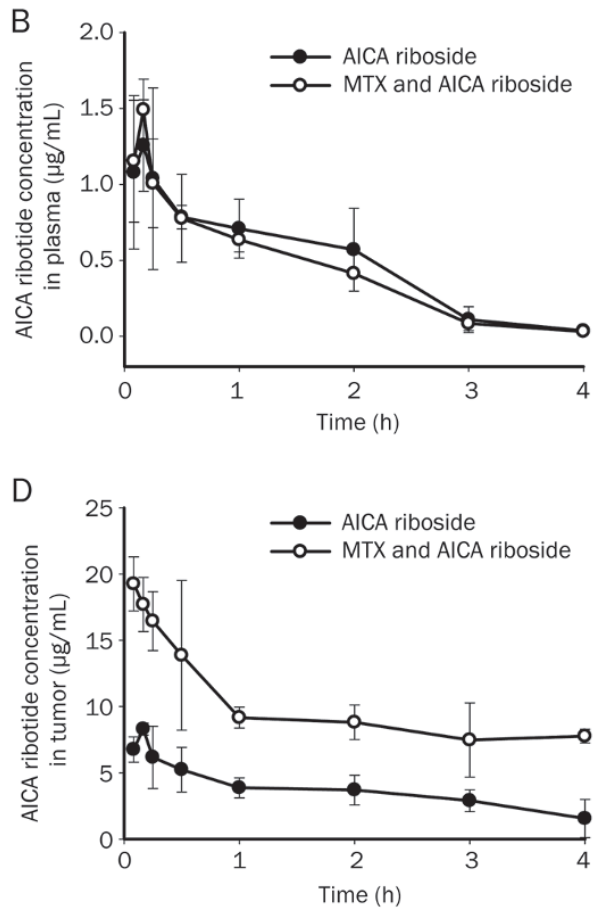

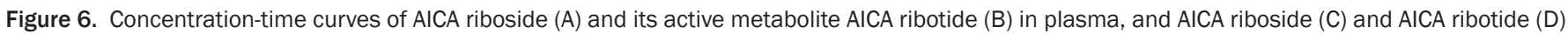
in tumor. 
$(P<0.01)$ and $19.80 \pm 1.32 \mu \mathrm{g} / \mathrm{mL}(P<0.001)$, respectively. Pharmacokinetic parameters are shown in Tables 1 and 2 . The $\mathrm{AUC}_{0-\mathrm{t}}$ of AICA riboside and AICA ribotide in tumors after iv administration of $200 \mathrm{mg} / \mathrm{kg}$ AICA riboside alone was $2.23 \pm 0.48$ and $14.86 \pm 1.67 \mu \mathrm{g} \cdot \mathrm{h} / \mathrm{mL}$, respectively. However, when the same dose of AICA riboside was administered iv at $4 \mathrm{~h}$ after $50 \mathrm{mg} / \mathrm{kg}$ MTX, the $\mathrm{AUC}_{0-\mathrm{t}}$ of AICA riboside and AICA ribotide in tumors was $4.36 \pm 0.89(P<0.05)$ and $38.95 \pm 3.03$ $\mu \mathrm{g} \cdot \mathrm{h} / \mathrm{mL}(P<0.001)$, respectively.

Table 1. Pharmacokinetic parameters of AICA riboside and its active metabolite AICA ribotide in plasma of nude mice bearing MCF-7 xenografts after iv administration of AICA riboside $(200 \mathrm{mg} / \mathrm{kg}$ ) or iv injection of the same dose of AICA riboside administered $4 \mathrm{~h}$ after iv $\operatorname{MTX}(50 \mathrm{mg} / \mathrm{kg})(n=3)$.

\begin{tabular}{lrr}
\hline \multicolumn{1}{c}{ Parameter } & AICA riboside & \multicolumn{1}{c}{$\begin{array}{c}\text { MTX and AICA } \\
\text { riboside }\end{array}$} \\
\hline AICA riboside & & \\
$\mathrm{AUC}_{0-\infty}(\mu \mathrm{g} \cdot \mathrm{h} / \mathrm{mL})$ & $8.01 \pm 1.96$ & $7.58 \pm 0.82$ \\
$\mathrm{MRT}_{0-\infty}(\mathrm{h})$ & $0.64 \pm 0.04$ & $0.65 \pm 0.14$ \\
$t_{1 / 2}(\mathrm{~h})$ & $0.44 \pm 0.02$ & $0.45 \pm 0.09$ \\
$\mathrm{CL}\left(\mathrm{L} \cdot \mathrm{h}^{-1} \cdot \mathrm{kg}^{-1}\right)$ & $24.96 \pm 6.10$ & $26.38 \pm 2.87$ \\
$\mathrm{~V}(\mathrm{~L} / \mathrm{kg})$ & $16.71 \pm 5.01$ & $17.62 \pm 5.55$ \\
& & \\
$\mathrm{AICA}$ ribotide & & $1.58 \pm 0.16$ \\
$\mathrm{AUC} \mathrm{C}_{0-\mathrm{t}}(\mu \mathrm{g} \cdot \mathrm{h} / \mathrm{mL})$ & $1.89 \pm 0.42$ & $1.04 \pm 0.20$ \\
$\mathrm{MRT}_{0-\mathrm{t}}(\mathrm{h})$ & $1.21 \pm 0.04$ & $1.51 \pm 0.16$ \\
$\mathrm{C}_{\text {max }}(\mu \mathrm{g} / \mathrm{mL})$ & $1.53 \pm 0.18$ & \\
\hline
\end{tabular}

Note: AUC is the area under the concentration versus time curve; MRT is mean residence time; $t_{1 / 2}$ was half-life; $C L$ is systemic clearance; $V$ is the apparent volume of distribution; and $C_{\max }$ is the observed maximum concentration.

Table 2. Pharmacokinetics parameters of AICA riboside and its active metabolite AICA ribotide in tumor of nude mice bearing MCF-7 xenografts after iv administration of AICA riboside $(200 \mathrm{mg} / \mathrm{kg}$ ) or iv injection of the same dose of AICA riboside administered $4 \mathrm{~h}$ after iv $\operatorname{MTX}(50 \mathrm{mg} / \mathrm{kg})(n=3)$. ${ }^{\mathrm{b}} P<0.05,{ }^{\mathrm{c}} P<0.01$ versus AICA riboside group.

\begin{tabular}{ccc}
\hline Parameter & AICA riboside & $\begin{array}{c}\text { MTX and AICA } \\
\text { riboside }\end{array}$ \\
\hline AICA riboside & & \\
$\mathrm{AUC}_{0-\mathrm{t}}(\mu \mathrm{g} \cdot \mathrm{h} / \mathrm{mL})$ & $2.23 \pm 0.48$ & $4.36 \pm 0.89^{\mathrm{b}}$ \\
$\mathrm{MRT}_{0-\mathrm{t}}(\mathrm{h})$ & $0.82 \pm 0.15$ & $0.82 \pm 0.23$ \\
$\mathrm{C}_{\max }(\mu \mathrm{g} / \mathrm{mL})$ & $4.49 \pm 0.82$ & $8.56 \pm 1.06^{\mathrm{c}}$ \\
$\mathrm{AICA} \mathrm{ribotide}_{\mathrm{AUC}}(\mu \mathrm{g} \cdot \mathrm{h} / \mathrm{mL})$ & & \\
$\mathrm{MRT}_{0-\mathrm{t}}(\mathrm{h})$ & $14.86 \pm 1.67$ & $38.95 \pm 3.03^{\mathrm{c}}$ \\
$\mathrm{C}_{\max }(\mu \mathrm{g} / \mathrm{mL})$ & $1.58 \pm 0.02$ & $1.70 \pm 0.16$ \\
\hline
\end{tabular}

Note: AUC is the area under the concentration versus time curve; MRT is mean residence time; and $C_{\max }$ is the observed maximum concentration.

\section{Discussion}

In most cases, combination chemotherapy is more effective than monotherapy ${ }^{[31,32]}$. Combination therapy can reduce side effects and prevent the emergence of resistance to anticancer drugs when drugs with different mechanisms of action are used in combination ${ }^{[21,22]}$. MTX is a classical folic acid antagonist ${ }^{[19]}$, whereas AICA riboside activates AMPK and subsequently inhibits energy-consuming processes, such as DNA synthesis, protein translation and lipogenesis ${ }^{[15]}$. The antitumor mechanisms of MTX and AICA riboside are complementary. Moreover, MTX can inhibit AICA ribotide transformylase, which converts AICA ribotide to 10 -formyl AICA ribotide ${ }^{[20]}$. This provides a reasonable rationale for using MTX and AICA riboside for combination chemotherapy. The main aims of this study were to investigate the combined effects of MTX and AICA riboside on tumor cell growth in vitro and in vivo, and to evaluate the influence of MTX on both AICA riboside and its active metabolite concentration in plasma and tumors. This is believed to be the first study to demonstrate that the combination of MTX and AICA riboside synergistically inhibits cancer cell growth in vitro and in vivo, and MTX increases AICA riboside and its active metabolite concentration in tumors.

Although AICA riboside is well tolerated ${ }^{[18]}$, the clinical use of AICA riboside is limited by the large amount needed to exert its effects ${ }^{[15]}$ and its poor pharmacokinetic profile. These shortcomings are associated in part with the rapid metabolism of AICA ribotide, which is converted to 10-formyl AICA ribotide by AICA ribotide transformylase. MTX polyglutamates can inhibit AICA ribotide transformylase activity. An in vitro study has shown that incubation of cells with $1 \mu \mathrm{mol} / \mathrm{L}$ MTX for $4 \mathrm{~h}$ resulted in accumulation and polyglutamylation of MTX in cells ${ }^{[33]}$. In the present study, MCF-7 and HepG2 cells were pretreated with $1 \mathrm{\mu mol} / \mathrm{L}$ MTX for $4 \mathrm{~h}$ before exposure to AICA riboside, and we investigated the influence of MTX on the ability of AICA riboside to activate AMPK. Western blotting and the AMPK activity assay (Figure 3) showed that MTX enhanced the ability of AICA riboside to activate AMPK. Interestingly, the results of Western blotting and the AMPK activity assay (Figure 3) showed that MTX also activated AMPK. A previous study has reported that MTX treatment blocked de novo purine biosynthesis, resulting in accumulation of the intermediate AICA ribotide ${ }^{[34]}$. We speculate that activation of AMPK by MTX may be attributed to both its inhibitory effect on AICA ribotide transformylase and its promotion of AICA ribotide accumulation.

The in vitro cytotoxicity assay (Figure 1) showed that the combination of MTX and AICA riboside exhibited more potent cytotoxicity against MCF-7 or HepG2 cells than either drug alone. MTX or AICA riboside alone only inhibited cancer cell proliferation, but the combination of MTX with AICA riboside resulted in cell killing. Combined treatment with 1 $\mu \mathrm{mol} / \mathrm{L}$ MTX and $1 \mathrm{mmol} / \mathrm{L}$ AICA riboside for $48 \mathrm{~h}$ killed $49.02 \% \pm 7.79 \%$ MCF-7 cells and $64.28 \% \pm 7.84 \%$ HepG2 cells. CI analysis (Figure 2) demonstrated that combined MTX and AICA riboside exhibited a broad range of synergism in inhib- 
iting the proliferation of MCF-7 and HepG2 cells.

In the MCF-7 cell xenograft model, the combination of MTX and AICA riboside had a superior antitumor effect to MTX or AICA riboside alone (Figure 5). Both MTX and AICA riboside were administered with a fixed schedule and dose. The observed synergism can be improved by modulating dosage and frequency of administration based on the pharmacokinetics and pharmacodynamics of both drugs.

MTX enhanced the AICA riboside and AICA ribotide concentration in tumors, but had no influence on their concentration in plasma (Figure 6). This could be because MTX is transported into cells via the reduced folate carrier and undergoes polyglutamation by folylpolyglutamate synthetase in cells, and MTX polyglutamates potently inhibit AICA ribotide transformylase, which converts AICA ribotide to 10-formyl AICA ribotide ${ }^{[20,35]}$.

Visentin et al have reported that pretreatment of HeLa cells with AICA riboside results in augmentation of MTX initial rates and net uptake in cells ${ }^{[36]}$. There may be an interaction between MTX and AICA riboside, and further studies on the influence of AICA riboside on the antitumor efficacy and pharmacokinetics of MTX are needed.

In conclusion, MTX enhances the anticancer potency of AICA riboside and significantly increases the concentration of both AICA riboside and its active metabolite AICA ribotide in tumors. MTX acts synergistically with AICA riboside to inhibit the proliferation of cancer cells and tumor growth in nude mice.

\section{Acknowledgements}

This work was supported by the Innovation Team of Ministry of Education, China (№ BMU20110263E).

\section{Author contribution}

Wei LU, Zai-quan LI, and Tian-yan ZHOU designed the research; Xiao-liang CHENG, Bo LI, and Meng-yao LI performed the research; Liang LI and Xiao-liang CHENG analyzed the data; and Xiao-liang CHENG, Tian-yan ZHOU, and Wei LU wrote the paper.

\section{References}

1 Sullivan JE, Carey F, Carling D, Beri RK. Characterisation of 5'AMP-activated protein kinase in human liver using specific peptide substrates and the effects of 5'-AMP analogues on enzyme activity. Biochem Biophys Res Commun 1994; 200: 1551-6.

2 Carling D. The AMP-activated protein kinase cascade - a unifying system for energy control. Trends Biochem Sci 2004; 29: 18-24.

3 Corton JM, Gillespie JG, Hawley SA, Hardie DG. 5-Aminoimidazole-4carboxamide ribonucleoside. A specific method for activating AMPactivated protein kinase in intact cells? Eur J Biochem 1995; 229: 558-65.

4 Hardie DG. The AMP-activated protein kinase pathway - new players upstream and downstream. J Cell Sci 2004; 117: 5479-87.

5 Hardie DG, Scott JW, Pan DA, Hudson ER. Management of cellular energy by the AMP-activated protein kinase system. FEBS Lett 2003; 546: 113-20.

6 Shaw RJ, Kosmatka M, Bardeesy N, Hurley RL, Witters LA, DePinho
RA, et al. The tumor suppressor LKB1 kinase directly activates AMPactivated kinase and regulates apoptosis in response to energy stress. Proc Natl Acad Sci U S A 2004; 101: 3329-35.

7 Shackelford DB, Shaw RJ. The LKB1-AMPK pathway: metabolism and growth control in tumour suppression. Nat Rev Cancer 2009; 9: 563-75.

8 Jones RG, Plas DR, Kubek S, Buzzai M, Mu J, Xu Y, et al. AMPactivated protein kinase induces a p53-dependent metabolic checkpoint. Mol Cell 2005; 18: 283-93.

9 Campas C, Lopez JM, Santidrian AF, Barragan M, Bellosillo B, Colomer $D$, et al. Acadesine activates AMPK and induces apoptosis in B-cell chronic lymphocytic leukemia cells but not in T lymphocytes. Blood 2003; 101: 3674-80.

10 Robert G, Ben Sahra I, Puissant A, Colosetti P, Belhacene N, Gounon $\mathrm{P}$, et al. Acadesine kills chronic myelogenous leukemia (CML) cells through PKC-dependent induction of autophagic cell death. PLoS One 2009; 4: e7889.

11 Saitoh M, Nagai K, Nakagawa K, Yamamura T, Yamamoto S, Nishizaki $\mathrm{T}$. Adenosine induces apoptosis in the human gastric cancer cells via an intrinsic pathway relevant to activation of AMP-activated protein kinase. Biochem Pharmacol 2004; 67: 2005-11.

12 Guan TJ, Qin FJ, Du JH, Geng L, Zhang YY, Li M. AICAR inhibits proliferation and induced S-phase arrest, and promotes apoptosis in CaSki cells. Acta Pharmacol Sin 2007; 28: 1984-90.

13 Xiang X, Saha AK, Wen R, Ruderman NB, Luo Z. AMP-activated protein kinase activators can inhibit the growth of prostate cancer cells by multiple mechanisms. Biochem Biophys Res Commun 2004; 321: 161-7.

14 Imamura K, Ogura T, Kishimoto A, Kaminishi M, Esumi H. Cell cycle regulation via $\mathrm{p} 53$ phosphorylation by a $5^{\prime}$-AMP activated protein kinase activator, 5-aminoimidazole-4-carboxamide-1-beta- $D$-ribofuranoside, in a human hepatocellular carcinoma cell line. Biochem Biophys Res Commun 2001; 287: 562-7.

15 Swinnen JV, Beckers A, Brusselmans K, Organe S, Segers J, Timmermans $L$, et al. Mimicry of a cellular low energy status blocks tumor cell anabolism and suppresses the malignant phenotype. Cancer Res 2005; 65: 2441-8.

16 Rattan R, Giri S, Singh AK, Singh I. 5-Aminoimidazole-4-carboxamide1-beta- $D$-ribofuranoside inhibits cancer cell proliferation in vitro and in vivo via AMP-activated protein kinase. J Biol Chem 2005; 280 : 39582-93.

17 Acadesine: AICA riboside, ARA 100, arasine, GP 1 110. Drugs R D 2008; 9: 169-75.

18 Dixon R, Gourzis J, McDermott D, Fujitaki J, Dewland P, Gruber H. AICA-riboside: safety, tolerance, and pharmacokinetics of a novel adenosine-regulating agent. J Clin Pharmacol 1991; 31: 342-7.

19 Faltaos DW, Hulot JS, Urien S, Morel V, Kaloshi G, Fernandez C, et al. Population pharmacokinetic study of methotrexate in patients with lymphoid malignancy. Cancer Chemother Pharmacol 2006; 58: 626-33.

20 Longo-Sorbello GS, Bertino JR. Current understanding of methotrexate pharmacology and efficacy in acute leukemias. Use of newer antifolates in clinical trials. Haematologica 2001; 86: 121-7.

21 Fan LL, Sun GP, Wei W, Wang ZG, Ge L, Fu WZ, et al. Melatonin and doxorubicin synergistically induce cell apoptosis in human hepatoma cell lines. World J Gastroenterol 2010; 16: 1473-81.

22 Oshima T, Cao X, Grande F, Yamada R, Garofalo A, Louie S, et al. Combination effects of SC144 and cytotoxic anticancer agents. Anticancer Drugs 2009; 20: 312-20.

23 Beckers A, Organe S, Timmermans L, Vanderhoydonc F, Deboel $\mathrm{L}$, Derua R, et al. Methotrexate enhances the antianabolic and 
antiproliferative effects of 5-aminoimidazole-4-carboxamide riboside. Mol Cancer Ther 2006; 5: 2211-7.

24 Vichai V, Kirtikara K. Sulforhodamine B colorimetric assay for cytotoxicity screening. Nat Protoc 2006; 1: 1112-6.

25 Zhou JR, Yu L, Mai Z, Blackburn GL. Combined inhibition of estrogendependent human breast carcinoma by soy and tea bioactive components in mice. Int J Cancer 2004; 108: 8-14.

26 Mai Z, Blackburn GL, Zhou JR. Soy phytochemicals synergistically enhance the preventive effect of tamoxifen on the growth of estrogendependent human breast carcinoma in mice. Carcinogenesis 2007; 28: 1217-23.

27 Chou TC, Talalay P. Quantitative analysis of dose-effect relationships: the combined effects of multiple drugs or enzyme inhibitors. Adv Enzyme Regul 1984; 22: 27-55.

28 Hardie DG, Salt IP, Davies SP. Analysis of the role of the AMPactivated protein kinase in the response to cellular stress. Methods Mol Biol 2000; 99: 63-74.

29 Cheng XL, Guo LP, Li ZQ, Li L, Zhou TY, Lu W. A HPLC method for simultaneous determination of 5-aminoimidazole-4-carboxamide riboside and its active metabolite 5-aminoimidazole-4-carboxamide ribotide in tumor-bearing nude mice plasma and its application to pharmacokinetics study. J Chromatogr B 2013; 915-916: 64-70.

30 Treon SP, Chabner BA. Concepts in use of high-dose methotrexate therapy. Clin Chem 1996; 42: 1322-9.

31 Romond EH, Perez EA, Bryant J, Suman VJ, Geyer CE Jr, Davidson NE, et al. Trastuzumab plus adjuvant chemotherapy for operable HER2positive breast cancer. N Engl J Med 2005; 353: 1673-84.

32 Adams GP, Weiner LM. Monoclonal antibody therapy of cancer. Nat Biotechnol 2005; 23: 1147-57.

33 Mauritz R, Peters GJ, Kathmann I, Teshale H, Noordhuis P, Comijn EM, et al. Dynamics of antifolate transport via the reduced folate carrier and the membrane folate receptor in murine leukaemia cells in vitro and in vivo. Cancer Chemother Pharmacol 2008; 62: 937-48.

34 Ha T, Baggott JE. 5-Aminoimidazole-4-carboxamide ribotide (AICAR) and its metabolites: metabolic and cytotoxic effects and accumulation during methotrexate treatment. J Nutr Biochem 1994; 5: 522-8.

35 Hider SL, Bruce IN, Thomson W. The pharmacogenetics of methotrexate. Rheumatology (Oxford) 2007; 46: 1520-4.

36 Visentin M, Zhao R, Goldman ID. Augmentation of reduced folate carrier-mediated folate/antifolate transport through an antiport mechanism with 5-aminoimidazole-4-carboxamide riboside monophosphate. Mol Pharmacol 2012; 82: 209-16. 